\title{
PHEF HEME PERFORMANCE (U)
}

\author{
by M. A. Baich
}

Westinghouse Savannah River Company

Savannah River Site

Aiken, South Carolina 29808

Other Authors:

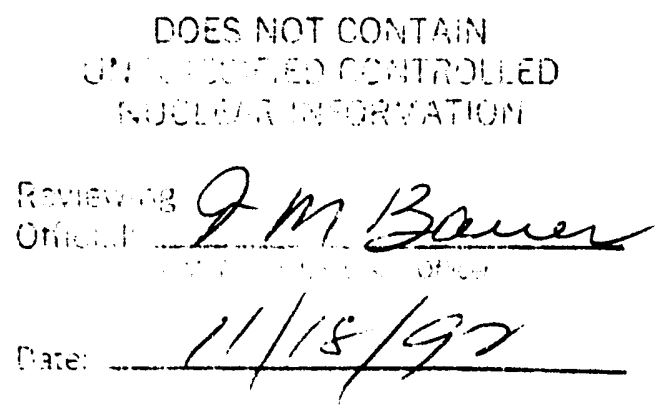

This paper was prepared in connection with work done under Contract No. DE-AC09-89SR18035 with the U.S. Department of Energy. By acceptance of this paper, the publisher and/or recipient acknowledges the U.S. Government's right to retain a nonexclusive, royalty-free license in and to any copyright covering this paper, along with the right to reproduce and to authorize others to reproduce all or part of the copyrighted paper. 


\section{DISCLAIMER}

This report was prepared as an account of work sponsored by an agency of the United States Government. Neither the United States Government nor any agency thereof, nor any of their employees, makes any warranty, express or implied, or assumes any legal liability or responsibility for the accuracy, completeness, or usefulness of any information, apparatus, product, or process disclosed, or represents that its use would not infringe privately owned rights. Reference herein to any specific commercial product, process, or service by trade name, trademark, manufacturer, or otherwise does not necessarily constitute or imply its endorsement, recommendation, or favoring by the United States Government or any agency thereof. The views and opinions of authors expressed herein do not necessarily state or reflect those of the United States Government or any agency thereof.

This report has been reproduced directly from the best available copy.

Available to DOE and DOE contractors from the Office of Scientific and Technical Information, P.O. Box 62, Oak Ridge, TN 37831; prices available from (615) 576-8401, FTS 626-8401.

Available to the public from the National Technical Information Service, U.S. Department of Commerce, 5285 Port Royal Rd, Springfield, VA 22161. 
Keywords: Precipitate Hydrolysis, Salt Processing Cell, HEME, SPC Vessel Vent System

Retention Period: Permanent

CC: E. W. Holtzscheiter, 773-A

J. E. Lunn, 704-T

J. T. Carter, 704-1T

R. A. Jacobs, 704-T

H. Shah, 704-1T

S. R. Young, 704-1T

SRTC Records (4)

August 15, 1992

To: L. F. LANDON, 704-T

From: M. A. BAICH, 704-T m. $\not B$.

PHEF HEME PEREORMANCE(U)

\section{INTRODUCTION}

The DWPF Salt Cell Vent Condenser (SCVC) includes a High Efficiency Mist Eliminator (HEME) designed to remove mercury aerosols that may form in the Precipitate Reactor (PR) condenser. The Savannah River Technology Center was requested by DWPF to make a performance assessment of a prototypic HEME element in the vent system of the Precipitate Hydrolysis Experimental Facility at TNX.a

\section{SUMMARY}

Pilot scale precipitate hydrolysis process simulations in PHEF have demonstrated that no operational difficulties are anticipated in DWPF due to HEME pluggage with organic materials. Pressure drop across the HEME was found to depend on several factors: vapor flow rate, benzene content of vapor stream, and process operational history. Observations indicate thac small amounts of high boiling organic compounds accumulate on the HEME during aqueous boiling. Increased inert purge appears to increase the rate of accumulation during this period. However, the organics are subsequently dissolved by benzene aerosols during benzene distillation in subsequent Organic Evaporator (OE) and PR cycles. Extended idle periods also appear to remove high boiling organic materials from the HEME by vaporization.

It is recommended that inert purge rates during aqueous boiling be kept to a minimum. Increased inert purge during organic boiling in the OE may be beneficial in removing any deposited organic materials at the expense of slightly increased benzene emissions. If deemed necessary, discontinuing chilled water flow to the vent condenser during periods of idle may also be used to remove high boiling organic eompounds if deemed necessary.

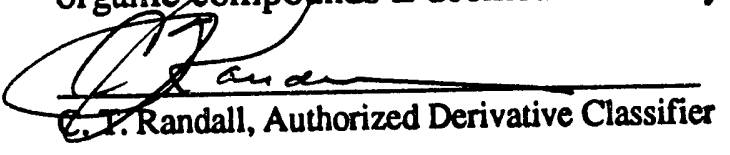

a. - J. F. Ortaldo to E. W. Holtzscheiter, "Installation of Prototypical HEME at PHEF", OPS-DTA-910032, June 18, 1991. 
HEME performance as regards to its efficiency for removing mercury aerosols was not assessed because the materials of construction of the PHEF PR are not sufficiently corrosion resistance to acidic solutions containing mercury.

\section{EOUIPMENT SETUP}

Due to time, schedule, and cost constraints, the installation of a scaled HEME in PHEF required using a separate HEME vessel as compared to the integrated HEME and Salt Cell Vent Condenser in DWPF. This vessel (depicted in Figure 1), was placed directly down stream of the existing PHEF vent condenser. The HEME was completely insulated to minimize condensation of benzene vapor (i.e. minimize cooling of the vapor exiting the condenser). The diameter and thickness of the HEME were set to match those of the Salt Cell Vent Condenser HEME, but the length was $1 / 5$ th as long to match the PHEF scale.

The HEME was instrumented with a delta pressure transmitter for pressure drop measurements and a standard bubbler for determination of the level in the liquid collection section. Two site ports were also installed for visual observations of the HEME surface. The existing vapor flowmeters were used for determining vapor flow rates through the HEME.

Figure 2 demonstrates the pressure drop versus flow character of the newly installed HEME. All performance data was compared to these data.

\section{DISCUSSION}

Since installation of the HEME, 6 hydrolysis runs using HAN (high nitrite feed) and 4 no-HAN runs using feed characteristic of "late wash" product have been run in PHEF. In addition, numerous PR aqueous boilup cycles have been run for decanter studies. No cleaning of the HEME was required to restore the HEME performance. Runs in PHEF have demonstrated no significant deviations in HEME pressure drop during process operation compared to that preaicted from clean HEME pressure drop data. The data indicates that the HEME will accumulate some high boiling organic materials during aqueous boiling but these deposits have been insufficient to lead to operational difficulties. Figure 3 shows a slight increase in HEME pressure drop following a precipitate reactor cycle. Continued process operation, as well as extended idle periods, were found to restore the HEME performance.

Visual observations of the HEME surface indicate no observable accumulation of material on the HEME surface other than a slight yellowish tint not present before HEME installation. As much as 8 to 10 liters of benzene aerosols were removed by the HEME during a single PR/OE cycle. Typical composition of this material is shown in Table I.

\section{CONCLUSIONS}

The materials collected by the HEME were found to be removed via two mechanisms: 1) dissolution by benzene aerosols during periods of benzene distillation (PR feeding or organic boiling in either the $\mathrm{PR}$ or the $\mathrm{OE}$ ), and 2) vaporization during idle periods. Consequently, no reduction in HEME life expectancy due to accumulation of organic material is expected in DWPF. 
TABLE 1. HEME ORGANIC ANALYSIS

SAMPLE P5020

\begin{tabular}{llll} 
COMPOUND & CONC. & \multicolumn{1}{c}{ UNITS } & \\
PHENYLBORIC ACID & 375 & $\mathrm{mg} / \mathrm{ml}$ \\
N-PHENYLFORMAMIDE & 413 & $\mathrm{mg} / \mathrm{ml}$ \\
ANALINE & 215 & $\mathrm{mg} / \mathrm{ml}$ \\
PHENOL & 15831 & $\mathrm{mg} / \mathrm{ml}$ \\
NITROBENZENE & 556 & $\mathrm{mg} / \mathrm{ml}$ \\
NITROSOBENZENE & 743 & $\mathrm{mg} / \mathrm{ml}$ \\
4-PHENYPHENOL & 847 & $\mathrm{mg} / \mathrm{ml}$ \\
2-PHENYLPHENOL & 5932 & $\mathrm{mg} / \mathrm{ml}$ \\
DIPHENYLAMINE & 30870 & $\mathrm{mg} / \mathrm{ml}$ \\
BIPHENYL & 66520 & $\mathrm{mg} / \mathrm{ml}$ \\
O-TERPHENYL & 2575 & $\mathrm{mg} / \mathrm{ml}$ \\
M-TERPHENYL & 1330 & $\mathrm{mg} / \mathrm{ml}$ \\
P-TERPHENYL & 341 & $\mathrm{mg} / \mathrm{ml}$
\end{tabular}




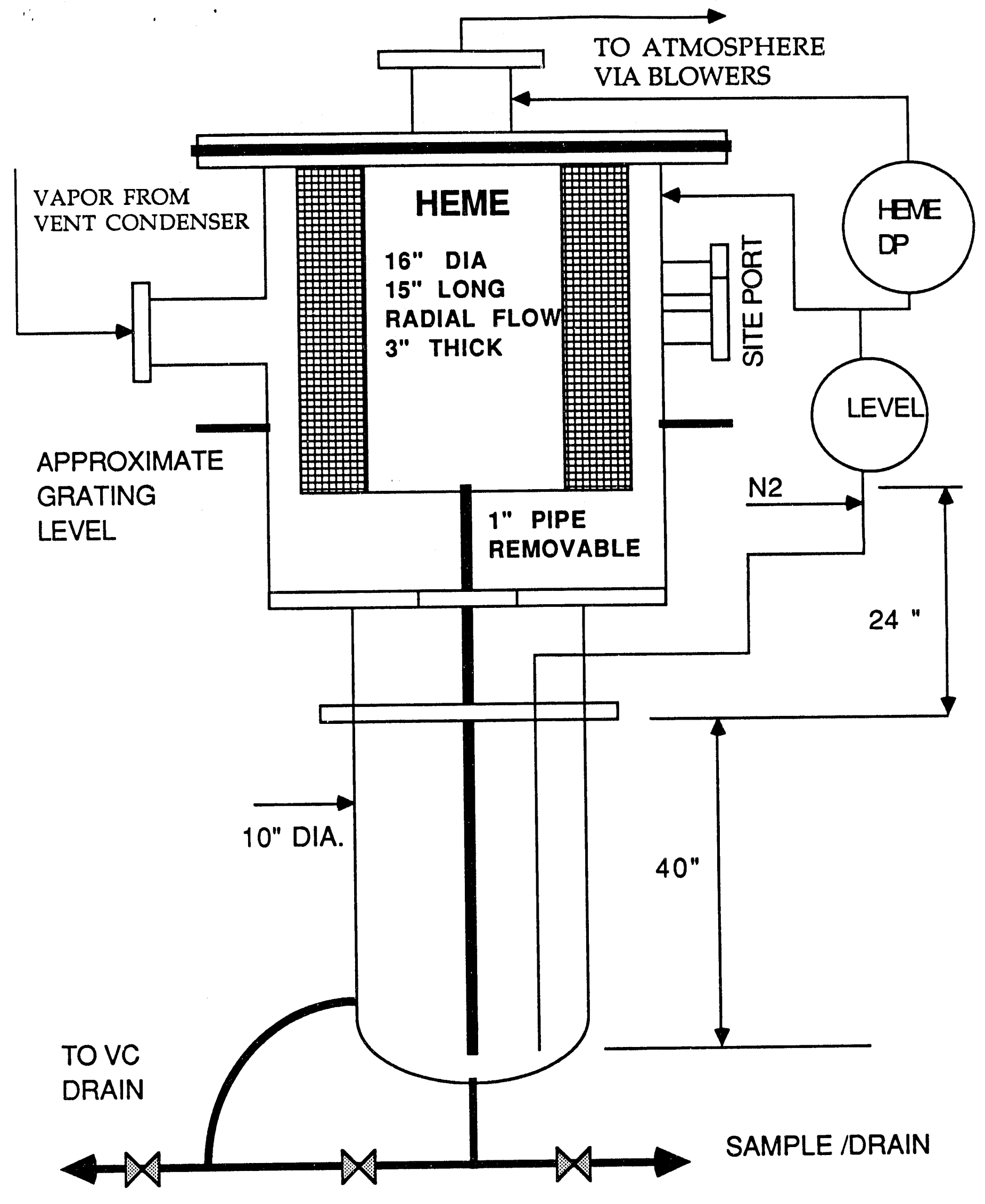

FIGURE 1. PHEF HEME SETUP

M. BAICH 6/91 


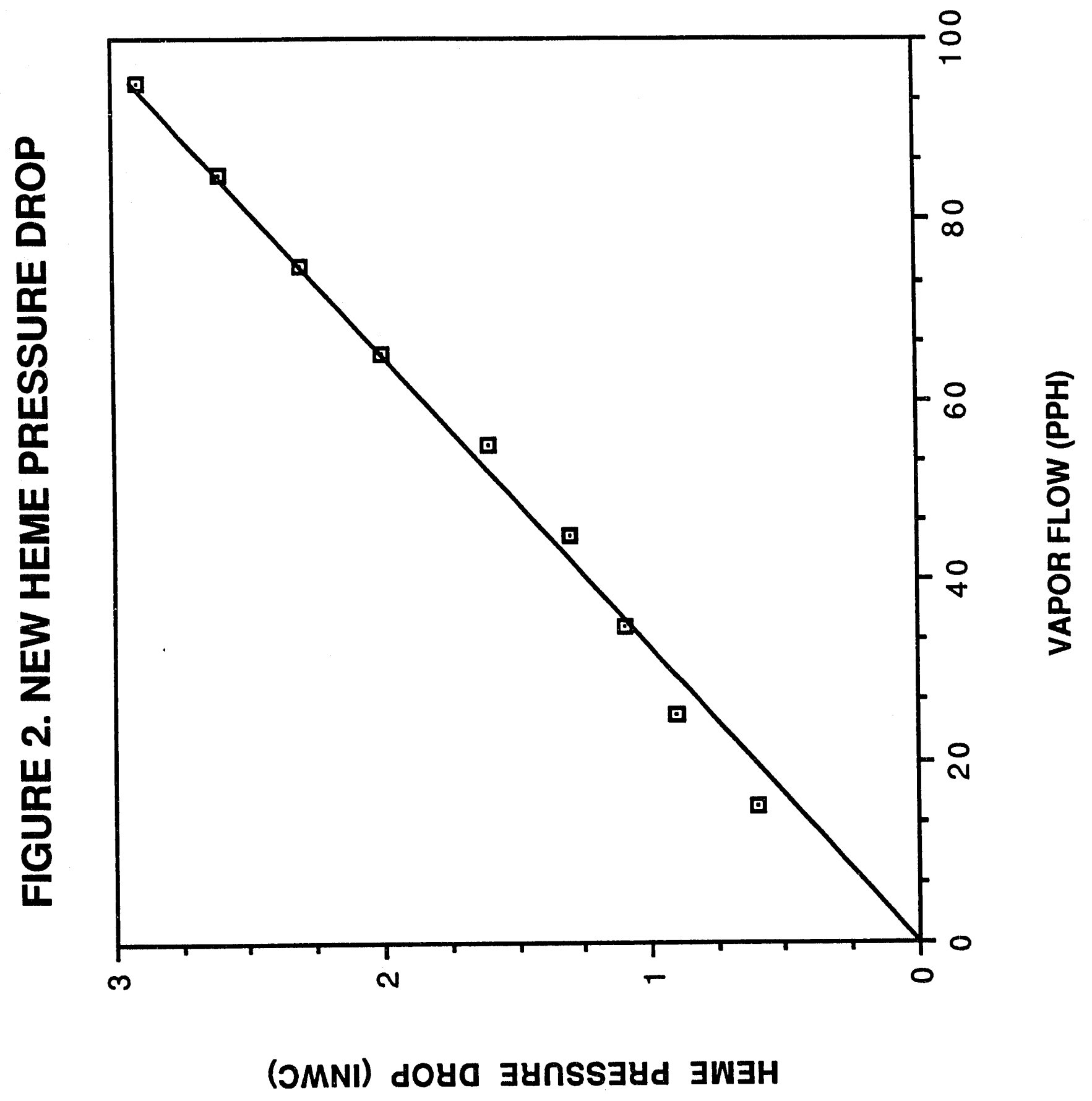




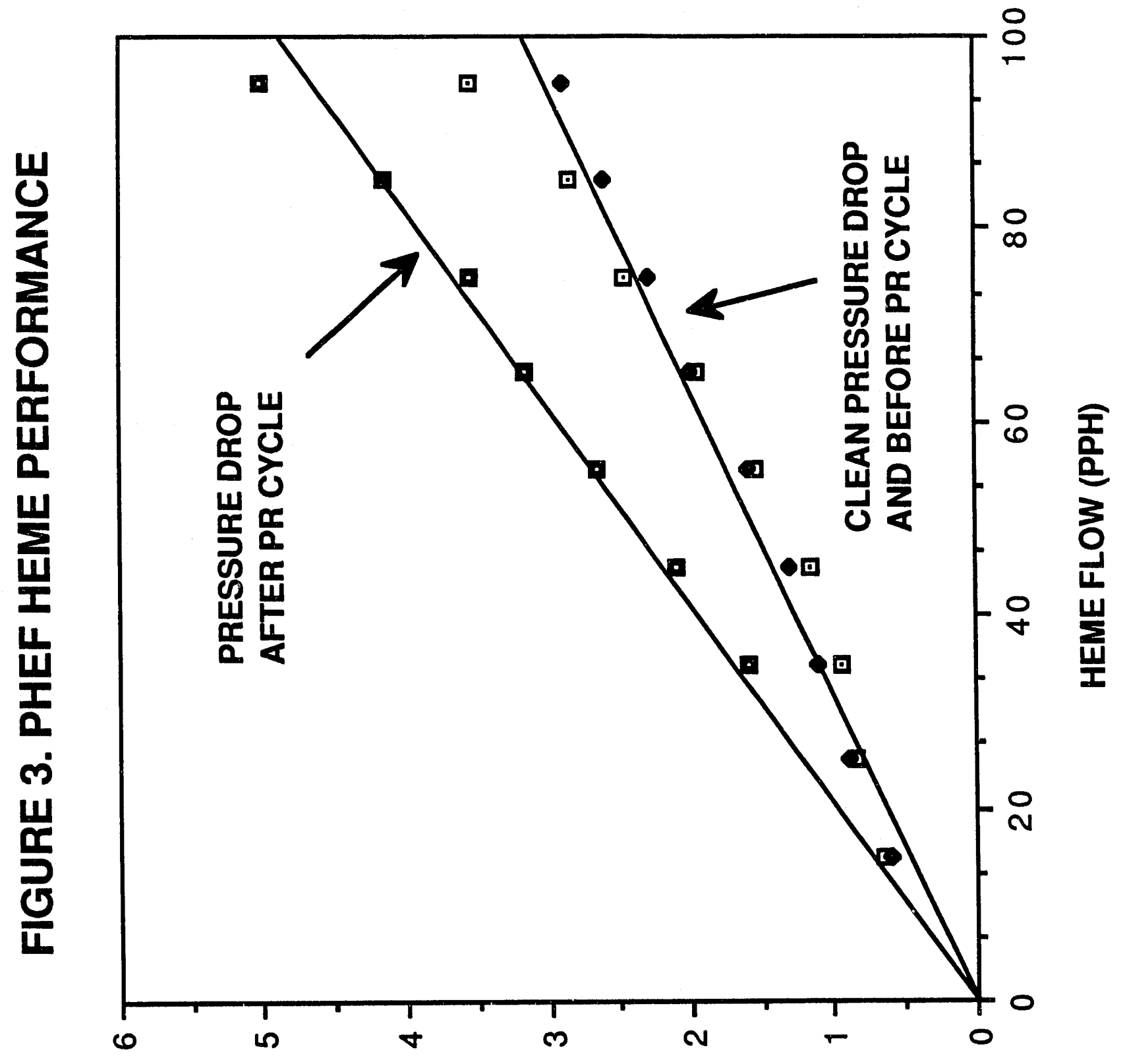

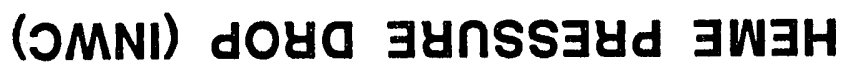



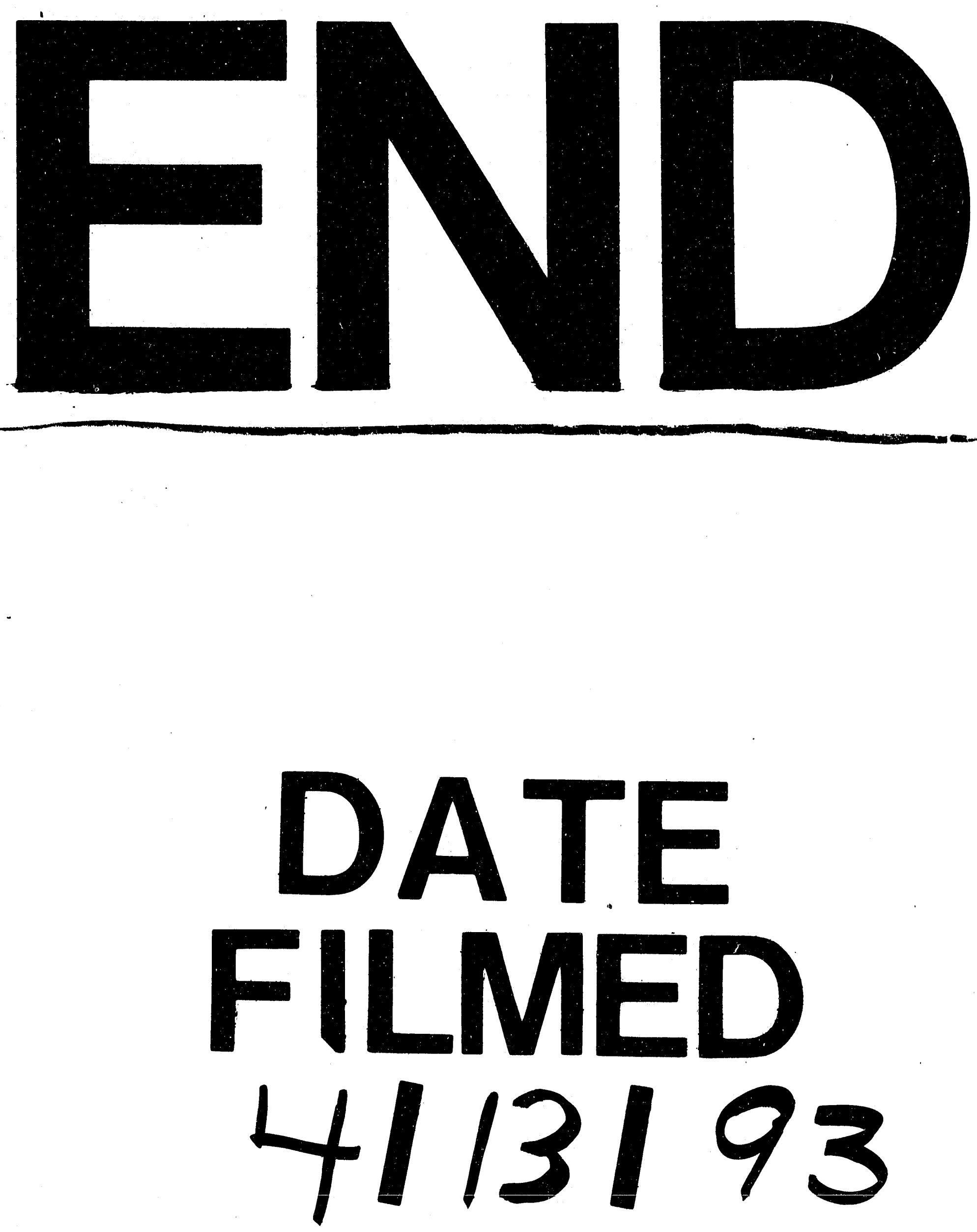
